\title{
Education as Foundation, Moral Education First---- Several Trials in Moral Education in Ideological and Political Education Teaching
}

\author{
Tong Fuchao \\ Mianyang Normal University, Sichuan Mianyang 621000
}

Keywords: Moral education; Students; Ideological and political education; Comprehensive development;

Abstract: As the backbone of China's future development, the students' quality level directly affects the construction of a harmonious society, so in recent years how to improve students' moral accomplishment has become a social focus. Ideological and political education, as an important course for students contact with Ideological and political education, economy, culture and social life, has played a positive role in the process of guiding students' comprehensive quality development, make students form correct ideological understanding and morality. Therefore, this article takes ideological and political education with moral education first as research direction takes the students as core research object, studies the moral education's importance, and effective countermeasures of moral education.

Ideological and political education teaching covers wide contents, including Ideological and political education, economics, culture, society, and many other aspects, and has a direct influence on students' comprehensive development. And ideological and political education curriculum development is not only beneficial to imparting knowledge, but the platform of students' quality level and moral formation, and is the main position of moral education. Therefore, how to combine moral education with students' development needs and ideological and political education organically is the demand of the course development, and is also known as the key point of education career innovative development.

\section{MORAL EDUCATION FIRST IS THE KEY TO IDEOLOGICAL AND POLITICAL EDUCATION}

Moral education is an important part to promote students' comprehensive development, which refers to various aspects training such as students' quality, political quality and moral quality. From a broad sense, moral education includes multiple parts, such as legal system education, psychological education, and adolescent education. Its teaching activities are carried out to meet the needs of students' physical and mental growth. Students are in the key stage of outlook on life, values and morality shaping. Sensitive heart and impulsive personality need right guidance, and moral education in ideological and political identity can act as a guide to guide student on the right track.

A. Extend functions and enrich the connotation of ideological and political education teaching Ideological and political teaching emphasizes on correct guide of students' thought, facilitates students to observe things around with reason, and be active, law-abiding citizens. But once lack the guide of moral education, ideological and political teaching will lose direction, and cause students pulled away from politics. This is because moral education has the function of thinking lead to help students correct ideological understanding, set up correct views and thoughts; and it has the function of mental stimulation, which can help students form patriotic consciousness, encourage students to fight, and stimulate learning motivation; and it has the function of law and moral guidance to help students understand legal common sense, and promote students know the law, further constrain on their own code of conduct; it has the function of psychological counseling to help students solve psychological problems, maintain healthy status of students, and lay a good foundation for the formation of students' values. Therefore ideological and political teaching cannot be without the support of moral education. Only facing up to moral education can we contribute to the realization of teaching goal, and enrich the connotation of ideological and political education teaching.

B. Reflect humanistic, and realize students' multifaceted development

In traditional ideological and political education, teaching with books as the core causes students 
thinking and thoughts severe hampers, and passive learning depresses students' intelligence development. This way of teaching produces vast majority of students who are of "high score, low-energy", and it does not consider the importance of ideological and political thinking from individuality, life, and social aspects. Ideological and political is not only a course spreading the concept of knowledge, but more a perception course. In the process of education, it needs to be people-oriented, and moral education oriented. Moral education already has the function of thoughts lead, spirit and moral guide, psychological counseling, which broadens moral education coverage to all the students. It is the respect for student individuality potential, and can help students understand the importance of ideological and political teaching from several aspects.

C. Capture requirements, and improve the significance of moral education

With the continuous development of Chinese society, students' daily lives are filled with too many uncertain factors: Internet provides student life, learning and growing with help, but it contains many negative elements, and easy to cause students addiction to the Internet, or wrong values and ideological understanding; In students' growth and development, the guide of parents cannot be ignored, but many parents can't accompany their children around because of work or other reasons. It is easy to cause students' psychological and growth problems which is not easy to be found in time, eventually they go down the wrong path. Many problems have brought adverse effects for all-round development of students, and moral education is to lead student growth and development, grasp the characteristics of the era and society. According to the characteristics of students, develop positive education, and make students form a grateful heart and a healthy attitude.

\section{THE EFFECTIVE IMPLEMENTATION OF MORAL EDUCATION FIRST}

Moral education first in ideological and political teaching needs to be conducted from many aspects: idea innovation, teaching methods improvement, abundant teaching means, and teaching system perfect and other aspects. Only by combining moral education into teaching process can we ensure the specificity, target, and comprehensiveness of moral education teaching.

A. Meet moral education function, and improve teachers'virtue quality

An old saying goes: "Teacher, pass knowledge and explain questions." Teachers in ideological and political teaching are the passers of knowledge, more thought leaders, who play an important role. Moral education first also needs teachers to play their important role. Therefore, the teachers must first know moral education from objective and systematic perspectives. Through the way of comparison, realize the flexibility, pertinence, and function of moral education in teaching, and actively introduce moral education in ideological and political education. In addition, moral education first is not without foundation, and its teaching activities need to be supported by teaching present situation, students' needs, and preparation factors.

In the present teaching situation and students demand, teachers need to combine with the performance of the students to understand the current teaching level, find the breakthrough point for moral education; at the same time, teachers can understand students' characteristics and needs by communication and observation analysis, and find the starting point of moral education.

Preparation factors refers to the improvement of teachers' ethics, that is teachers improve themselves, promote their own quality level, improve moral accomplishment, and implement " Learned Teacher, Moral Model." Only in this way can they play their role models. At the same time, teachers should pay attention to fully show inner "moral" in their words and deeds on the optimization to let students experience the charm of "moral", and form the correct impact on the students imperceptibly. "Moral" in also reflects itself in the external dress support. Students are in youth rebellious period, which are also relatively blind on personal needs, and often advocate personality exaggerated clothing. And teachers should let students realize the proper dress is also a kind of beauty.

B. Grasp teaching purpose, and combine book knowledge

The introduction of teaching idea, quality character preparation, and language external influence can only open a door for moral education teaching. To improve the overall level of moral education teaching, teachers should combine moral education with book knowledge together from teaching 
objectives to promote moral education first be rational. The content of ideological and political education covers widely. In order to improve students' perception for life, enable students to have a correct understanding, and rational knowledge things around through the introduction of contents such as law, economy, and culture. But essentially, Ideological and political education is based on Marxist theory as the main line, which can offer stable support for moral education teaching, but too much written language description often leads to students' lost interest in learning, not to mention the education of personal emotion, and attitude and values. Therefore, the teacher should take the growth of the students' needs as the basis, on the basis of determining teaching objective, combine students' life and moral education, ideological and political teaching together, to enrich and expand book knowledge as far as possible.

As Cliff Baker said: "we should not regard morality as end in itself, but should see it way to lead to a better life." In the process of carrying out ideological and political education, teachers should try to introduce moral education to life, from life and higher than life, so as to reduce the distance between the students and ideological and political teaching. For example, in economic life teaching, surrounding the teaching tasks, the teachers not only need to let students understand the present production and economic system, understand the development of socialist market economy system, at the same time, also need to promote students to form correct consumption view, rational knowledge of social development, economic development, thus see China's economy from a more assertive state. Therefore, in economic life teaching, systematic theoretical knowledge, there is also a key point of moral education teaching. In order to promote normal conduct of moral education teaching, the teacher can collect materials from life, and let the student summarize their consumption concept. In addition, teachers can enumerate different consumption cases to let the student talk about whether the consumption view is right or wrong in combination with their own life experiences. This kind of life moral education teaching also can break classroom boundary, solve students' ideological understanding confusion points, difficult points and provide support for the development of students' ideological concept.

C. Flexible use of information technology and rich forms of moral education

Driven by high speed information technology, ideological and political education fuses richer, wonderful elements, and information technology also brings a steady stream of energy for moral education: network provides moral education with diversified information. To a certain extent, broaden students' view, expand the channels of knowledge, explore their wisdom and strengthen the interaction and communication between students, and provide help to solve problems of physical and mental development. But at the same time, the teacher should also see network is two-sided through information technology use to build moral education model.

For this, the teacher first should actively use slides, video, audio, and other resources in information technology, multimedia technology in moral education teaching, thus to improve the vitality, vividness of book knowledge, make rational knowledge can be converted into perceptual, specific instructions, deepen students understanding of the truth and improve the persuasion and appeal powers of moral education curriculum. At the same time, multimedia teaching can fully arouse student's enthusiasm, initiative, and has great help to create interactive and three-dimensional classroom. At the same time, the teacher can also move moral education to campus network or other education platforms, arrange teaching tasks, let the students independently collect relevant online teaching materials, and strengthen the cooperation between students, and fuse material into teaching process. To promote the development of students' creative thinking, and at the same time realize knowledge layers infiltration of moral education. In order to pass Chinese cultural heritage and innovation training of students and form correct national and moral spirit, for example, in order to deepen students' understanding of Chinese culture, feel its long and profound history. The teacher can encourage the students to collect Chinese traditional cultural art elements in the network, and summarize the elements of China's current economic, cultural, political, and many other effects. This form promotes the students in the process of information integration, deeply comprehend Chinese culture, form the love of Chinese traditional culture and art, but also deeply understand the spirit of Chinese nation. In class, the teacher can also deepen the separate communication with 
students through E-mail, qq, and other social networking platforms, understand student's thought development and growing demand in time, thus provide more help for students learning and living to make students form good quality.

D. Design teaching activity, and promote infection

In order to promote flexible, vivid, and visualized moral education, teachers should give students enough time and platform. Through a variety of activities add more visual and influencing elements to moral education. Usually, teachers can mainly carry out activity types: practice exercise, scene simulation, role playing, theme discussion, etc. Among them, practice is to provide students with a certain opportunities, make their own hands-on practice activities to improve ideological understanding, and promote the moral development; Scenario simulation refers to that teachers create a certain situation for the students, let the students put themselves in the environment and atmosphere, and strengthen the feeling of moral education; Role play is to let students play different characters, which can make them understand knowledge from various angles, understand developmental shortcomings, and form a correct concept of value; Decorating theme discussion refers to teachers assign topics, and let the students discuss their views through personal or groups discussions. In the activities process, implementation cannot only improve students' communication ability, but can let the student recognize their own deficiencies, and realize the comprehensive development of students.

To let the student feel deep political life, foster a sense of ownership, for example. Teachers can simulate the situation of democratic election, let student role play, respectively state how to vote, in what ways can the election be made? As a citizen, what should we do in the process of election? And then let the students contact life to answer, which political rights and freedom do Chinese citizens enjoy? Give their ideas in participation in political life. These activities are carried out to improve students' comprehension ability of democracy, and form correct patriotic consciousness to active participates in social activities.

\section{CONCLUSION}

With the development of Chinese education career in full swing, how to effectively realize moral education is a key point to promote students' comprehensive development, form correct ideological understanding and values. In the process of ideological and political education, the teacher should face up to the importance of moral education. On the basis of outstanding students' subject position, with the introduction of a correct concept of education and a variety of education method, set up perfect education system, and combine moral education with ideological and political education in order to achieve the ultimate goal of promoting students comprehensive development.

\section{ACKNOWLEDGEMENT}

Subject: Influence and countermeasures research on college students' ideological and moral education in view of network news spread (MYZD15-04)

\section{REFERENCE}

[1] Sun Dehua. The function of moral education in ideological and political education [J]. Journal of Hulun Buir College, 2012,06: 22-25.

[2] Li Lei. Analyze moral education penetration in ideological and political teaching [J]. Journal of New Curriculum Learning (Middle), 2014,07: $141+143$.

[3] Liu Dan, Cao Yang. On the moral education mission of ideological and political education [J]. China, 2012, 28:144. 